\title{
Embryonic development of the southern surf crab Ovalipes trimaculatus (Decapoda: Brachyura: Portunoidea)
}

\author{
Antonela Martelli ${ }^{1,2}$, Federico Tapella ${ }^{3}$, Ximena González-Pisani ${ }^{1}$, Fernando Dellatorre ${ }^{1,4}$, \\ Pedro J. Barón 1,4 \\ ${ }^{1}$ Centro para el Estudio de Sistemas Marinos - Consejo Nacional de Investigaciones Científicas y Técnicas (CESIMAR- \\ CONICET). Edificio CCT CONICET-CENPAT, Boulevard Brown 2915, Puerto Madryn (9120), Chubut, Argentina. \\ E-mail: martelli@cenpat-conicet.gob.ar \\ ${ }^{2}$ Centro Regional Universitario Bariloche - Universidad Nacional del Comahue (CRUB-UNComa). Quintral 1250, Bari- \\ loche (8400), Río Negro, Argentina. \\ ${ }^{3}$ Centro Austral de Investigaciones Científicas - Consejo Nacional de Investigaciones Científicas y Técnicas (CADIC - \\ CONICET), Bernardo A. Houssay 200, V9410CAB - Ushuaia, Tierra del Fuego, Argentina \\ ${ }^{4}$ Sede Puerto Madryn - Facultad de Ciencias Naturales - Universidad Nacional de la Patagonia San Juan Bosco (FCN - \\ UNPSJB). Boulevard Brown 3051, Puerto Madryn (9120), Chubut, Argentina.
}

\begin{abstract}
Summary: The embryogenesis of Ovalipes trimaculatus, a member of the highly valued portunid swimming crabs, was studied under nearly constant temperature $\left(13 \pm 1^{\circ} \mathrm{C}\right)$, salinity $(33)$ and photoperiod $(14 \mathrm{~h}$ light: $10 \mathrm{~h}$ dark) conditions. A five-stage scale of embryonic development was defined for the species. Time required to complete development averaged $35.7 \pm 2.11$ days, showing no significant differences between embryos located in inner, middle and outer portions of the egg mass. The egg chorion was rounded and showed the highest growth in diameter between stages I (morula-blastula-gastrula) and II (primordium of larval structure) and between stages III (appendage formation) and IV (eye formation). Results reported here provide a baseline for optimizing hatchery operations and useful information for management purposes.
\end{abstract}

Keywords: crustacean; crabs, aquaculture; Ovalipes trimaculatus; embryology.

Desarrollo embrionario del cangrejo nadador Ovalipes trimaculatus (Decapoda: Brachyura: Portunoidea)

Resumen: Se estudió la embriogénesis del cangrejo nadador Ovalipes trimaculatus, miembro de la familia de portúnidos altamente valorados, bajo condiciones constantes de temperatura $\left(13 \pm 1{ }^{\circ} \mathrm{C}\right)$, salinidad $(33)$ y fotoperíodo (luz $14 \mathrm{~h}$ : $10 \mathrm{~h}$ oscuridad). Se definió una escala de cinco etapas de desarrollo embrionario para la especie. El tiempo necesario para completar el desarrollo es de $35.7 \pm 2.11$ días, sin mostrar diferencias significativas entre embriones ubicados en porciones interior, media y exterior de la masa de huevos. Los huevos son esféricos y presentan mayor crecimiento en diámetro entre las etapas I (mórula - blástula - gástrula) y II (primordio de estructuras larvarias) y entre las etapas III (formación de apéndices) y IV (formación de los ojos). Los resultados aquí presentados proporcionan la base para la optimización del cultivo y brindan información útil para el manejo de la especie.

Palabras clave: crustáceos; cangrejos; acuicultura; Ovalipes trimaculatus; embriología.

Citation/Como citar este artículo: Martelli A., Tapella F., González-Pisani X., Dellatorre F., Barón P.J. 2016. Embryonic development of the southern surf crab Ovalipes trimaculatus (Decapoda: Brachyura: Portunoidea). Sci. Mar. 80(4): 499-509. doi: http://dx.doi.org/10.3989/scimar.04404.17B

Editor: P. Abelló.

Received: January 15, 2016. Accepted: September 27, 2016. Published: October 18, 2016.

Copyright: (C) 2016 CSIC. This is an open-access article distributed under the terms of the Creative Commons Attribution (CC-by) Spain 3.0 License.

\section{INTRODUCTION}

Among the brachyurans, portunids stand out as highly valued fisheries and aquaculture species on account of their export potential and high nutritional value (Josileen 2011). Since worldwide captures of this resource reached their asymptote at 90 million tonnes 20 years ago (FAO 2015), unmet demands 
have led to overexploitation of several local resources. This has promoted research on breeding techniques to restock overfished areas (Allan and Fielder 2004) and to enhance production through aquaculture (Allan and Fielder 2004, Davis et al. 2004b, Heasman and Fielder 1983, Lindner 2005). While China, Indonesia and USA report the highest captures worldwide (FAO 2015), India, Micronesia, Philippines and Vietnam are pillars of the breeding industry, where hatcheries have achieved efficient development and growth (Catacutan et al. 2003, Lindner 2005, Quinitio 2009).

Crustaceans show great variability in stages and total duration of their embryonic development, resulting from evolutionary adaptations (Scholtz and Dohle 1996, Dohle et al. 2004, Scholtz and Wolff 2013) and from physiological modulation by environmental conditions (Hamasaki et al. 2003, Bas et al. 2008). The knowledge of this part of the ontogeny is not only of intrinsic scientific interest but also a prerequisite for developing hatchery and nursery practices (Davis et al. 2004b, Zmora et al. 2005, Quinitio 2009). Also, it can be used in forecasting temporal patterns of larval production for fisheries management purposes (Stevens et al. 2008). In most species, embryonic development is one of the phases of the life cycle that are most sensitive to environmental stressors (MacDonald et al. 1988, Lee et al. 1996), so its characterization under normal conditions is required to understand their effects.

Although embryogenesis in brachyurans is a continuous process, partition in steps or stages of development, defined by the most important morphological changes, is a useful tool for their characterization (Moriyasu and Lanteigne 1998). The transit through successive stages of embryonic development includes changes in both shape and size (Hines 1982). Eggs vary in shape, from spherical to elliptical, and can change from one to the other during development (García-Guerrero and Hendrickx 2004). In studied portunids, eggs sphericity is maintained throughout development, except in some species where slight ellipticity is observed at the onset of eye formation (Samuel and Soundarapandian 2009, Ates et al. 2012). In some members of this family, the size of eggs right after spawning is positively correlated with the size of the progenitor female, but this is not a general rule (Haddon 1994, Samuel and Soundarapandian 2009, Ravi and Manisseri 2013). On the other hand, egg size increase is an intrinsic ontogenetic process occurring gradually through embryogenesis and culminating at a faster rate at the end of development (Churchill 2003, Josileen 2011).

The southern surf crab, Ovalipes trimaculatus (de Haan, 1833), is a portunid with continuous distribution on the mid-latitude $\left(25-45^{\circ} \mathrm{S}\right)$ marine coasts of the Southern Hemisphere, reported in Argentina, Australia, Brazil, Chile, Japan, South Africa, Australia, Peru, Uruguay and some islands of the Indian and Pacific Oceans (Arnaud et al. 1972, Melo 1996, Alvarez et al. 2009). It is a fast-growing (Barón, unpublished data), highly valued species (Dima et al. 2012, 2014), and therefore a good candidate for local aquaculture. It is targeted by artisanal fisheries using trawl and seine nets, baited traps and scuba diving (Boschi 1997), and is suitable for processing into a diversity of consumer products (Dima et al. 2009).

Although there is detailed information on most stages of the $O$. trimaculatus life cycle (Fenucci and Boschi 1975, Dellatorre et al. 2014, Vallina et al. 2014), there is still a knowledge gap on the phase of embryonic development. The aim of this work is to characterize the morphological changes during embryogenesis, as well as the duration of the process and the embryonic survival. The results are expected to be useful to complement the available information on its life cycle, which will allow the comparison of evolutionary traits with other related species, and to provide important knowledge for the design of hatchery practices.

\section{MATERIALS AND METHODS}

\section{Specimen collection and experimental design}

Twenty-six ovigerous $O$. trimaculatus females carrying embryos at the earliest stage of development (i.e. morula in the first or second cell division) were hand-collected by SCUBA diving on subtidal sand bottoms of Nuevo Gulf near the city of Puerto Madryn, Argentina $\left(42^{\circ} 25^{\prime} \mathrm{S}, 64^{\circ} 07^{\prime} \mathrm{W}\right)$ during the reproductive season (October-December) of 2014. Specimens were transported to the Experimental Marine Aquarium of the National Patagonian Centre (CCT CONICET-CENPAT), where they were acclimated in plastics tanks containing filtered seawater with continuous aeration. The females were marked using coloured rubber bands placed around the cephalothorax between the chelipeds and the first pair of pereiopods, in such a way that these could not be removed. The maximum widths of their carapaces and abdomens were measured with a digital caliper to the nearest 0.1 millimetre at the beginning of the experiments.

Seawater temperature during embryonic incubation experiments was set at $13 \pm 1^{\circ} \mathrm{C}$ (mean \pm sd), simulating not only the seawater temperature at the time of crab collection but also the average surface seawater temperature during the reproductive season (Dellatorre et al. 2012). Salinity was kept at $33 \pm 1$ (mean \pm sd), resembling typical values from waters of Nuevo Gulf (Rivas and Ripa 1989), and photoperiod was fixed at $14 \mathrm{~h}$ light:10 h dark, emulating the natural light cycle at the time of experimentation. The crabs were fed fish meat once a week and $20 \%$ of the seawater volume in the tanks was renewed daily.

To allow important relevant developmental changes to be observed through embryogenesis while minimizing animal stress, females were randomly sorted into three groups in which individual egg masses were sampled: 1) weekly $(\mathrm{n}=10) ; 2)$ three times per week $(n=10)$; and 3$)$ once, after hatching (control; $n=6)$. The control group was used to determine the total duration of embryonic development without causing any stress. Taking into account that differences in the rate of oxygen delivery to embryos could have effects on their survival and on the duration of embryogenesis (Fernández and Brante 2003), three $\geq 10$ egg-samples (i.e. developing embryos) were carefully excised from 
the inner (i.e. deep, near the bases of the pleopods), middle (i.e. at mid-depth) and outer parts (i.e. on the external surface) of the egg mass on each sampling. Eggs were taken using thin surgical forceps, placed in seawater on excavated slides and examined "in vivo" under an Olympus stereomicroscope with total magnification of $100 \times$. Based on changes in morphological and physiological characters such as yolk colour, yolk content (\%), development of appendages, chromatophores and eye pigmentation, five stages were defined to characterize the embryonic development. Representative morphological features of each of the stages were photographed using a Nikon D3000 digital camera.

\section{Observations, measurements and calculations}

Since preliminary observations showed significant shrinkage and deformation of eggs preserved in fixing solutions, all measurements were made on fresh samples. Fifty eggs from each development stage, ten from each of five different females, were used for measurements. These eggs were individualized with forceps under a dissecting stereomicroscope (Olympus CH30) with total magnification of $10 \times$ and photographed using a Nikon D3000 digital camera. Resulting images were then processed using the ImageJ program to obtain three orthogonal measurements of egg diameter. Except for the earliest developmental stage, from morula to gastrula, these corresponded to the body axes of embryos: Diameter I (DI, antero-posterior axis), Diameter II (DII, ventro-dorsal axis), and Diameter III (DIII, latero-lateral axis). Based on these, several morphometric variables were calculated, including area (A), volume (V), ellipticity (e) and elongation (E) as defined by Stevens (2006):

$$
\mathrm{A}=\pi \mathrm{r}^{2},
$$

where $r$ is half of the mean egg diameter;

$$
V=1 / 6 \pi d^{3},
$$

where $\mathrm{d}$ is the mean egg diameter;

and

$$
\mathrm{e}=\frac{\mathrm{DI}}{\mathrm{DII}}
$$

$$
\mathrm{E}=\frac{\mathrm{DI}-\mathrm{DII}}{\mathrm{DI}+\mathrm{DII}}
$$

The standard colour of live embryos was determined following the Pantone ${ }^{\circledR}$ Colour Formula Guide (Pantone Inc., Carldtadt, USA) and was recorded as P followed by the number that represents the code of the Pantone colour scale.

The relative duration of each embryonic stage $\left(\mathrm{RDE}_{\mathrm{i}}\right)$ was estimated as

$$
\mathrm{RDE}_{\mathrm{i}}=\frac{\mathrm{DE}_{\mathrm{i}}}{\mathrm{DE}} 100,
$$

where $\mathrm{DE}_{\mathrm{i}}$ is the absolute duration of embryonic stage $\mathrm{i}$ and DE is the total length of embryogenesis.
Since it has been reported that $O$. trimaculatus suffers substantial egg loss during embryonic development (Brante et al. 2004), and considering that in many crustacean species egg cleaning results in the nonselective detachment of embryos from the egg mass (Brante et al. 2004), estimation of embryonic mortality is not straightforward for the species. Instead, based on the assumption that embryos remain attached to the egg mass during brief periods after death, "instantaneous embryonic mortality" at the end of stage $\mathrm{i}\left(\mathrm{EM}_{\mathrm{i}}\right)$ was estimated as

$$
\mathrm{EM}_{\mathrm{i}}=\frac{\mathrm{D}_{\mathrm{i}}}{\mathrm{T}} 100
$$

where $D_{i}$ is the number of dead embryos in a sample of the egg mass taken at the end of stage $\mathrm{i}$ and $\mathrm{T}$ is the total number of eggs in the same sample, including live and dead embryos. Embryos were considered dead when yolk had a different colour or texture to those of its neighbours. In stages II to $\mathrm{V}$, when the embryo was clearly distinguishable, yolk droplets were smaller and dispersed around the embryo.

Similarly, instantaneous mortality from the end of the last stage of embryonic development to the end of hatching $\left(\mathrm{EM}_{\mathrm{h}}\right)$ was estimated as

$$
\mathrm{EM}_{\mathrm{h}}=\frac{\mathrm{D}_{\mathrm{h}}}{\mathrm{T}} 100
$$

where $D_{h}$ is the number of dead embryos found in samples of the egg mass and $\mathrm{T}$ is the total number of eggs, including broken egg capsules remaining attached to the pleopods after hatching.

To measure heartbeat frequency of embryos in an advanced stage of development, the beating of 10 embryos' hearts was counted for a minute and then averaged.

\section{Data analysis}

When normality (Kolmogorov-Smirnov test) and homoscedasticity (Fisher test) assumptions were fulfilled, differences in mean values of different morphometric variables between different stages of embryonic development were tested using one-way analysis of variance (ANOVA), followed by post hoc comparisons between stages using Tukey tests. Otherwise, non-parametric Kruscal-Wallis tests and Dunn post hoc tests were used. The Spearman correlation test was used to observe the relation between the carapace width of females and the dimensions of their eggs.

\section{RESULTS}

Ovigerous females used for the incubation experiments ranged from 63.4 to $99.2 \mathrm{~mm}$ in carapace width and 17.2 to $31.5 \mathrm{~mm}$ in abdomen width. Optimum egg sampling frequency to detect important changes during embryogenesis was three times a week. Survival of ovigerous females during the experiments was $100 \%$ for the control group and $90 \%$ for the groups of females whose eggs were sampled weekly and three times a week. 
A1

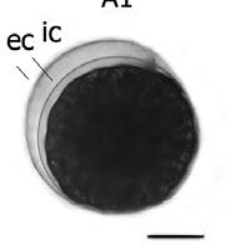

A5

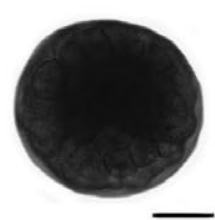

C1

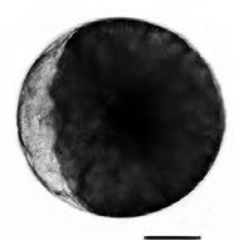

e D1

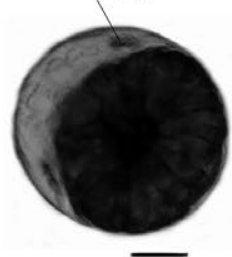

E1

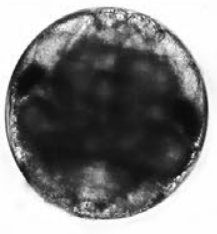

E5

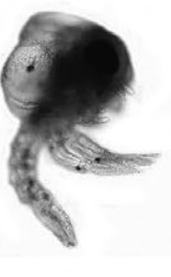

A2

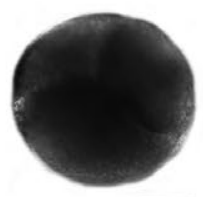

B1

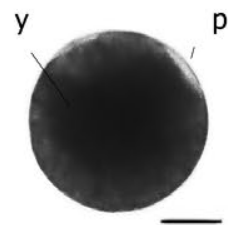

C2

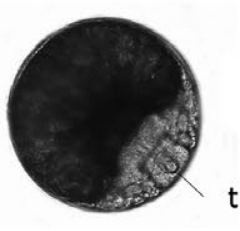

D2

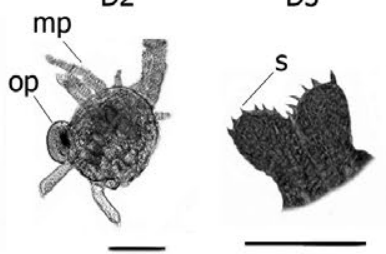

E2

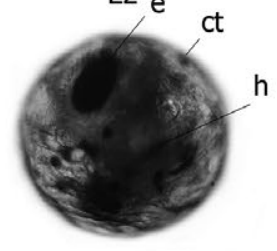

E6

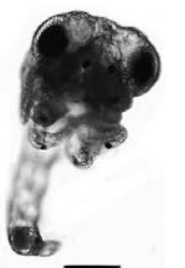

A3

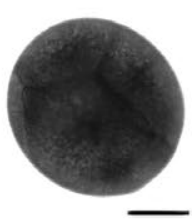

B2
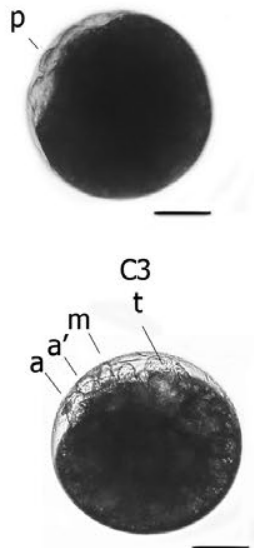

D4

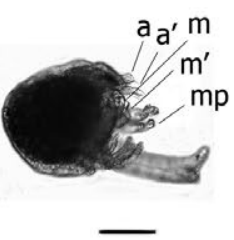

E3

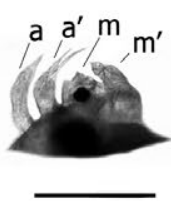

E7

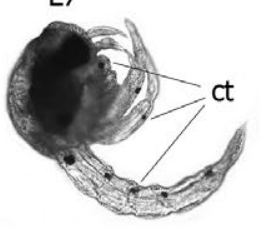

A4

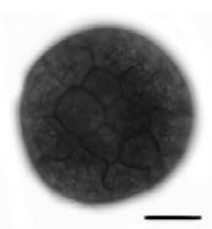

B3

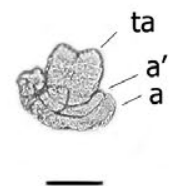

C4

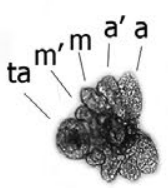

D5

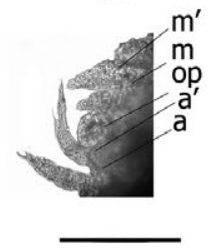

E4

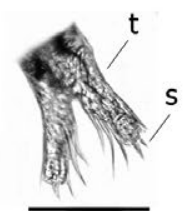

E8

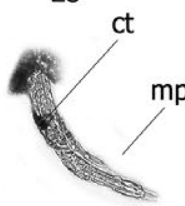

Fig. 1. - Morphological changes in the eggs and embryos of Ovalipes trimaculatus during the embryological development stages (stage I, A1-A5; Stage II, B1-B3; stage III, C1-C4; stage IV, D1-D5; stage IV, E1-E8). Scale bar = 100 um (A1 at D2; D4; E1; E2; E5 and E6). Scale $\mathrm{bar}=50 \mu \mathrm{m}$ (D3; D5; E3; E4; E6). References: antenna (a'); antennule (a); chromatophores (ct); external cover (ec); eye (e); heart formed (h); internal cover (ic); maxilla (m'); maxillipeds (mp); maxillule (m); optic globe (op); primordial structures (p); setae (s); telson (t); thoracic-abdominal buds (ta); yolk (y).

Five stages of embryonic development were defined for $O$. trimaculatus based on several morphological characteristics, as described below:

\section{Stage I}

After fertilization, eggs are spherical, 309.76 \pm 7.13 $\mu \mathrm{m}$ in diameter and intense orange-coloured (P. 123)
(Fig. 1: A1-A5). Two transparent membranes, inner and outer (Fig. 1: A1), cover the egg, whose volume is completely occupied by yolk. The external egg cover is adhesive at spawning and projects into a funiculus that holds the egg attached to the female's pleopod setae. After cell division starts (Fig. 1: A2), slender grooves delineate polygonal areas on the egg surface, and the centrolecytic zygote progressively transforms into 
Table 1. - Kruskal-Wallis tests for differences in values of egg morphometric variables between stages of embryonic development of Ovalipes trimaculatus. RDE, relative duration of embryonic stage; DI-DIII, egg diameters; A, area; V, volume; E, elongation and e, ellipticity. Values are mean \pm standard deviation; $n=$ number of eggs analysed. See detailed description of morphometric dimensions, indexes and colours in the section of Materials and Methods.

\begin{tabular}{lcccccc}
\hline & Stage I & Stage II & Stage III & Stage IV & Stage V & $\begin{array}{c}\text { Kruskal-Wallis Test significance } \\
\text { and } \mathrm{p} \text { values }\end{array}$ \\
\hline RDE $(\%)$ & $26.76 \pm 2.58$ & $22.36 \pm 2.76$ & $22.38 \pm 2.10$ & $16.19 \pm 1.75$ & $13.3 \pm 1.29$ & $\mathrm{p}<0.01$ \\
D I & $307.26 \pm 9.10$ & $324.26 \pm 11.97$ & $328.8 \pm 16.92$ & $364.76 \pm 18.11$ & $368.36 \pm 15.96$ & $\mathrm{H}=176.96 ; \mathrm{p}<0.01$ \\
D II & $312.26 \pm 8.38$ & $329.72 \pm 13.17$ & $333.16 \pm 14.827$ & $370.36 \pm 16.69$ & $376.12 \pm 18.89$ & $\mathrm{H}=178.34 ; \mathrm{p}<0.01$ \\
D III & $311.06 \pm 7.83$ & $325.4 \pm 11.61$ & $330.1 \pm 15.47$ & $361.78 \pm 19.42$ & $368.16 \pm 16.48$ & $\mathrm{H}=180.42 ; \mathrm{p}<0.01$ \\
A & $493.98 \pm 11.31$ & $520.48 \pm 18.181$ & $552.82 \pm 21.52$ & $581.97 \pm 29.21$ & $589.70 \pm 22.95$ & $\mathrm{H}=183.96 ; \mathrm{p}<0.01$ \\
V & $165.54 \pm 3.73$ & $174.56 \pm 5.85$ & $175.29 \pm 6.89$ & $195.80 \pm 8.74$ & $197.15 \pm 6.29$ & $\mathrm{H}=183.96 ; \mathrm{p}<0.01$ \\
E & $0.008 \pm 0.016$ & $0.008 \pm 0.017$ & $0.004 \pm 0.017$ & $0.007 \pm 0.013$ & $0.010 \pm 0.016$ & $\mathrm{p}=0.4488$ \\
e & $1.016 \pm 0.033$ & $1.017 \pm 0.036$ & $1.009 \pm 0.035$ & $1.016 \pm 0.028$ & $1.021 \pm 0.034$ & $\mathrm{P} 469$ \\
Colour & $\mathrm{P} 123$ & $\mathrm{P} 157$ & $\mathrm{P} 484$ & $\mathrm{P} 464$ & 50 & 50.4489 \\
$\mathrm{n}$ & 50 & 50 & 50 & 50 & & \\
\hline
\end{tabular}

morula (Fig. 1: A3), blastula and gastrula. In contrast, in unfertilized eggs the outer cover and the egg yolk are not in contact (Fig. 1: A1). No organ structures are observed at this stage, which lasts $9.65 \pm 1.01$ days, representing an RDE of $26.76 \pm 2.58 \%$ (Table 1 ).

\section{Stage II}

Eggs are spherical, 326.99 $\pm 11.17 \mu \mathrm{m}$ in diameter and orange-coloured (P. 157) (Fig. 1: B1-B3). The embryonic primordium becomes evident as a translucent bulge on the egg's surface at the animal pole (Fig. 1: B1), which represents the ventral region of the developing embryo. Rudiments of some embryonic appendages become visible as a long pair of preoral structures emerging along the antero-posterior axis, the antennules being the first, followed by a shorter pair of antennae (Fig. 1: B2). Both appendages are uniramous and elongated. The posterior thoracoabdominal plate has a short, wide projection with its distal extremity bifurcated into the two lobes of the forming telson (Fig. 1: B3). The yolk content represents approximately $90 \%$ of the egg volume. Stage duration is $8.10 \pm 0.94$ days, which represents an RDE of $22.36 \pm 2.76 \%$ (Table 1 ).

\section{Stage III}

Eggs are spherical, $331.98 \pm 18.38 \mu \mathrm{m}$ in diameter and dark-red coloured (P. 484) (Fig. 1: C1-C4). The stage begins when the first three pairs of appendages (i.e. antennule, antennae and mandible) are formed (Fig. 1: C3, C4). Developing structures represent approximately $40 \%-50 \%$ of the egg volume, the rest being yolk. The antennule and antenna are tube-shaped structures without setae, growing caudally parallel to each other while mandibles become comparatively smaller (Fig. 1: C3, C4). As this stage progresses, abdominal somites and elongated rudiments of the rest of the appendages form posteriorly. At the distal end of the abdomen, the telson is biforked, still without setae. Afterwards, maxillule, maxillae and first and second maxillipeds form, while crescent-shaped carapace rudiments appear on the anterior part of the cephalothorax. At the end, four short terminal setae appear on each telson lobe. The stage lasts $7.83 \pm 0.90$ days, which represents an RDE of $22.38 \pm 2.10 \%$ (Table 1 ).

\section{Stage IV}

Eggs are spherical, 367.56 $\pm 16.69 \mu \mathrm{m}$ in diameter and brown-coloured (P. 464).). Pigmented eyes are first visible (Fig. 1: D1). The antennules are uniramous and longer than antennae, displaying two long terminal setae. The antennae are uniramous and with two terminal setae. The maxillule and maxilla are uniramous. The optic lobes are well developed, showing a pigmentation pattern consisting of a dark curved line growing from the antennule side of the compound eyes (Figs. 1: D4, D5). The first and second maxillipeds are biramous, with three terminal setae at the end of the endopods (Fig. 1: D4). The abdomen grows continuously incorporating segments. In the biforked telson, four pairs of setae are visible on each lobule (Fig. 1: D3). At the end, yolk reserves are significantly reduced to approximately $30 \%$ to $40 \%$ of the egg volume. Stage duration is $5.59 \pm 0.66$ days, which represents an RDE of $16.19 \pm 1.75 \%$ (Table 1$)$.

\section{Stage V}

Eggs are spherical, 372.24 $16.32 \mu \mathrm{m}$ in diameter and dark brown-grey coloured (P. 469) (Fig. 1: E1E8). The yolk is reduced to a few droplets in the dorsal part of the embryo and its volume progressively reduces through this stage while the embryo grows (Fig. 1: E1). Heartbeat and dorsal spine become first noticeable and body motion can be observed. Dot-like pigmented chromatophores appear on the bases of the mandibles and maxillipeds and on each abdominal segment (Fig. 1: E2-E8). Pigmentation on the ocular globe expands and increases while the compound eye enlarges. A transversal pigmented line appears on the mouth. At the middle of this stage the eyes are completely formed and pigmented (Fig. 1: E2). The uniramous antennule displays two terminal setae. The biramous antenna has a short and wide endopodite with one seta and an exopodite with two setae. The mouth has a large chromatophore with horseshoe shape and spots of pigments on each side of mouth. The first maxilliped has a chromatophore on the long coxa; its endopodite and exopodite have two and four terminal setae, respectively. The second maxilliped displays a chromatophore on the coxa. The exopodite has four terminal setae. Neither pereiopods nor pleopods can 

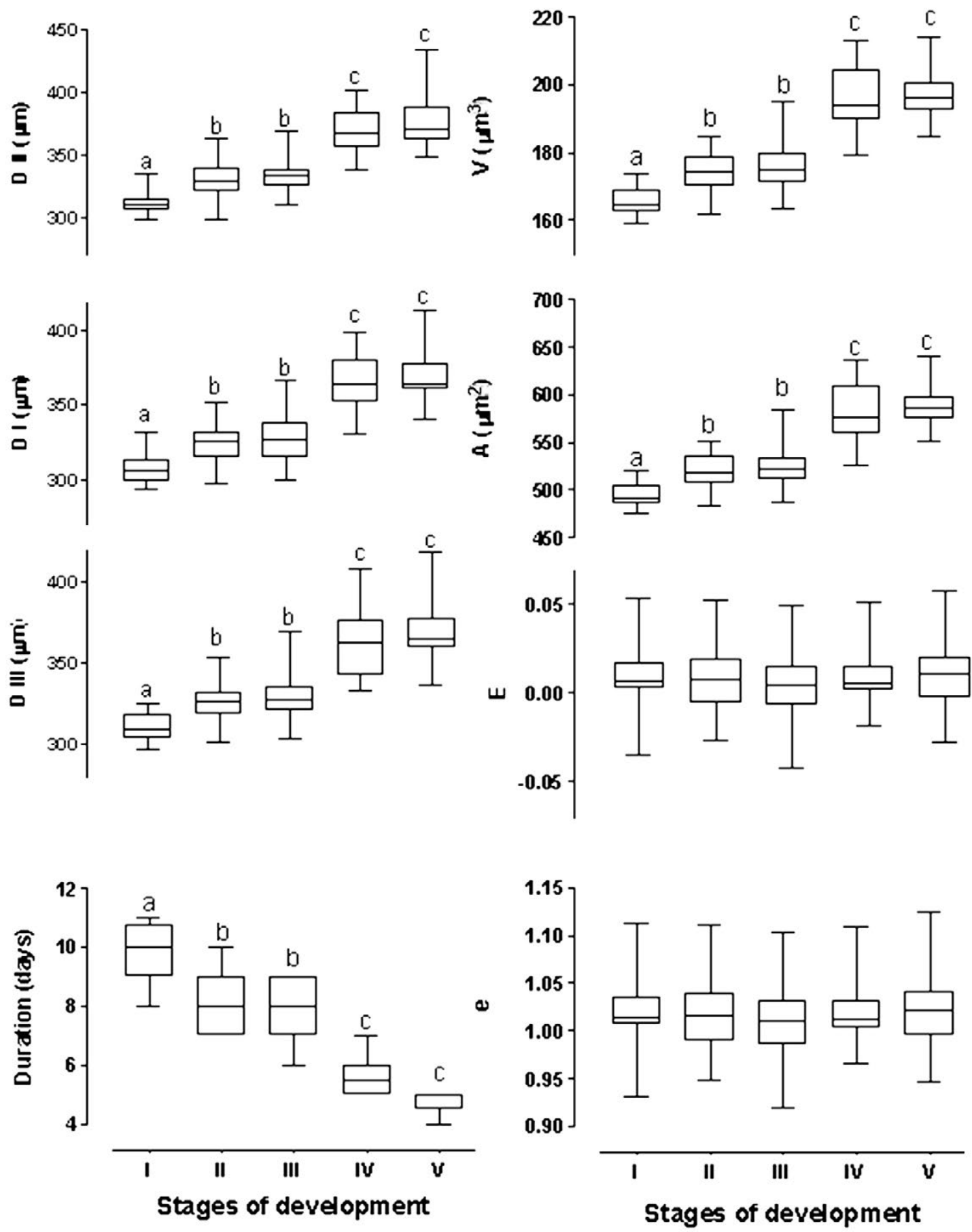

Fig. 2. - Boxplots of three different dimensions of eggs and indexes of egg shape during successive stages of embryonic development of Ovalipes trimaculatus. Different letters denote significant differences between stages using the Dunn test. Detailed descriptions of egg dimensions and indexes are included in the Material and Methods section.

be observed. The abdomen has five segments, with the sixth fused to the telson (Fig. 1: E4). All of these segments have chromatophores on each side. The biforked telson has six terminal setae on each lobe. Sporadic motions of the appendages and abdomen can be observed, becoming more frequent by the time of hatching. The cardiac frequency is approximately 180.62 per minute. This stage ends just before hatching, and lasts $4.76 \pm 0.42$ days, which represents an RDE of $13.3 \pm 1.29 \%$. (Table 1 )
When embryonic development completes, females induce hatching by flapping their abdomens and rhythmically moving their pleopods. Egg hatching starts by breaking of the chorion in the anterior zone, above the cephalic part of embryos. Hatching of the entire brood occurs in a single pulse between the first night and early morning hours. Empty chorionic membranes stay adhered to pleopods until the next moult.

Egg sampling frequency had no significant effect on the total duration of embryogenesis (ANOVA: $F=2.81$; 
Table 2. - Instantaneous embryonic mortality (EM) of Ovalipes trimaculatus at the end of different stages of development and hatching. $\mathrm{H}$, hatching. Different letters denote significant differences of post hoc comparisons for each location in all stage of development. EM values are mean \pm standard deviation; $n=$ number of samples with egg mass analysed (10 eggs per sample).

\begin{tabular}{ccccc}
\hline $\begin{array}{c}\text { Stage of embryonic } \\
\text { development }(i)\end{array}$ & $\begin{array}{c}\mathrm{EM}_{\text {s-i }}(\%) \\
\text { Inner }\end{array}$ & $\begin{array}{c}\mathrm{EM}_{\text {s-i }}(\%) \\
\text { middle }\end{array}$ & $\begin{array}{c}\mathrm{EM}_{\text {s-i }}(\%) \\
\text { outer }\end{array}$ & $\mathrm{n}$ \\
\hline I & $0.00^{\mathrm{a}}$ & $0.00^{\mathrm{a}}$ & $0.00^{\mathrm{a}}$ & 20 \\
II & $0.00^{\mathrm{a}}$ & $0.00^{\mathrm{a}}$ & $0.00^{\mathrm{a}}$ & 20 \\
III & $1.00 \pm 2.61^{\mathrm{a}}$ & $1.42 \pm 3.63^{\mathrm{a}}$ & $1.45 \pm 2.75^{\mathrm{ab}}$ & 20 \\
IV & $0.00^{\mathrm{a}}$ & $0.00^{\mathrm{a}}$ & $0.00^{\mathrm{a}}$ & 20 \\
V & $0.25 \pm 1.12^{\mathrm{a}}$ & $0.00^{\mathrm{a}}$ & $0.42 \pm 2.04^{\mathrm{a}}$ & 20 \\
H & $3.50^{\mathrm{b}}$ & $3.50^{\mathrm{b}}$ & $3.50^{\mathrm{b}}$ & 10 \\
\hline
\end{tabular}

$\mathrm{p}=0.083 ; \mathrm{df}=23)$. The relative position of embryos in the egg mass (inner, middle or outer) did not significantly affect the duration of development (ANOVA; $\mathrm{F}=0.14 ; \mathrm{p}=0.8727$; $\mathrm{df}=69$ ), so O. trimaculatus embryogenesis is synchronous for all embryos carried by a single mother. The average total length of embryogenesis was $35.7 \pm 2.11$ days $(n=24)$ from the earliest stages of development (i.e. 2 or 4-cell morula) to hatching. To evaluate the survival of embryos, a two-way Kruskal-Wallis test for (instantaneous embryonic mortality) was applied, with relative position of embryos in the egg mass and stage of embryonic development as the explaining variables. While significant differences were found $(\mathrm{H}=50.59 ; \mathrm{p}<0.01)$, post hoc comparisons (Dunn test) revealed that embryonic mortality was higher at hatching than at the end of each of the stages of embryonic development, and that position of eggs in the egg mass had no effects on survival of embryos at $13^{\circ} \mathrm{C}$ and constant aeration (Table 2).

No significant correlation was found between the dimensions of recently extruded $(\rho=0.15)$ or pre-hatched $(\rho=0.44)$ eggs and the carapace width of the brooding females. Therefore, morphometric data of eggs were pooled together for comparisons between embryonic stages. As shown by the elongation (E) and ellipticity (e) indexes, eggs were spherical and preserved their shape throughout all developmental stages (Fig. 2; Table 1). Increases in egg area (A) and volume (V) were observed during development, but egg size differences were significant only in the transition from stage I to II and from stage III to IV (Table 1).

\section{DISCUSSION}

Cellular differentiation in crustacean embryos starts soon after gastrulation and requires enormous energy expenditure (Soundarapandian et al. 2013). Some authors consider that the main events of the embryonic development occur from the onset of cleavage to the formation of gastrula (Nagao et al. 1999, Müller et al. 2003), but changes occurring during this period are difficult to observe in live eggs without special techniques. After inward blastoderm migration by cellular proliferation into the yolk mass (Adiyodi 1988), primordial structures start growing and extend ventrally, being easy to observe and describe in live eggs. Therefore, stages of embryonic development of crustaceans are generally defined based on distinctive external morphological features such as the proportion of yolk relative to total embryonic volume, appearance of the primordium, degree of development of appendages, pigmentation of the ocular globe, formation of chromatophores, and initiation of heartbeat (Nagao et al. 1999). Although a more detailed description of development could have been achieved by characterizing additional stages of embryonic development, in this study external characteristics useful for rapid and easy classification during hatchery operations or population field studies were used to define developmental stages based on general criteria used for decapods (Felder et al. 1985).

Eye formation follows the pattern described for the crustacean vision ontogeny (Cronin and Jinks 2001). The general sequence of ontogenic changes observed during the embryogenesis (Table 3) and the increase in size and complexity of abdominal and ocular pro-

Table 3. - Comparison of the embryogenesis in several portunid species

\begin{tabular}{|c|c|c|c|c|c|}
\hline \multirow[t]{2}{*}{ Species } & \multirow[b]{2}{*}{$\begin{array}{c}\text { Blastula-cleavage- } \\
\text { gastrula } \\
\text { (mean diameter) }\end{array}$} & \multicolumn{3}{|c|}{ Embryonic development and mean diameter } & \multirow[t]{2}{*}{ References } \\
\hline & & $\begin{array}{l}\text { Primordium } \\
\text { of embryo - eye } \\
\text { placode }\end{array}$ & $\begin{array}{l}\text { Organogenesis- } \\
\text { pigment appears }\end{array}$ & $\begin{array}{l}\text { Chromatophores appear- } \\
\text { heartbeat }\end{array}$ & \\
\hline Charybdis feriata & $\begin{array}{l}\text { Spherical shape } \\
0.298-0.36 \mathrm{~mm}\end{array}$ & $\begin{array}{l}\text { Spherical shape } \\
40 \mathrm{~mm}\end{array}$ & $\begin{array}{l}\text { Elliptical shape } \\
0.42 \mathrm{~mm}\end{array}$ & $\begin{array}{c}\text { Spherical shape } 0.369-0.45 \\
\mathrm{~mm}\end{array}$ & $\begin{array}{l}\text { Sundarapandian et al. 2013, } \\
\text { Josileen } 2011\end{array}$ \\
\hline Portunus pelagicus & $\begin{array}{c}\text { Spheric shape } \\
0.307 \pm 0.037 \mathrm{~mm}\end{array}$ & $\begin{array}{c}\text { Spherical shape } \\
0.386 \pm 0.039 \mathrm{~mm}\end{array}$ & & $\begin{array}{c}\text { Spherical shape } \\
0.396 \pm 0.033 \mathrm{~mm}\end{array}$ & $\begin{array}{l}\text { Ikhwanuddin et al. 2012, } \\
\text { Ravi } 2013\end{array}$ \\
\hline P. sanguinolentus & $\begin{array}{l}\text { Spherical shape } \\
0.34 \mathrm{~mm}\end{array}$ & $\begin{array}{l}\text { Spherical shape } \\
0.41 \mathrm{~mm}\end{array}$ & $\begin{array}{l}\text { Spherical shape } \\
0.48 \mathrm{~mm}\end{array}$ & $\begin{array}{l}\text { Elliptical shape } 0.57-0.64 \\
\text { mm. Posteriorly spheric } \\
\text { shape } 0.73 \mathrm{~mm}\end{array}$ & $\begin{array}{l}\text { Samuel and } \\
\text { Soundarapandian } 2009\end{array}$ \\
\hline Scylla serrata & $\begin{array}{c}\text { Spherical shape } \\
0.34 \mathrm{~mm} \\
0.40 \mathrm{~mm}\end{array}$ & $\begin{array}{l}\text { Spherical shape } \\
0.41 \mathrm{~mm} \\
0.52 \mathrm{~mm}\end{array}$ & $\begin{array}{c}\text { Spherical shape } \\
0.48 \mathrm{~mm} \\
0.60 \mathrm{~mm}\end{array}$ & $\begin{array}{c}\text { Elliptical shape. } 0.65 \mathrm{~mm} \text {. } \\
\text { Posteriorly spheric shape } \\
0.73 \mathrm{~mm}\end{array}$ & $\begin{array}{l}\text { Samuel and } \\
\text { Soundarapandian 2009, } \\
\text { Ates et al. } 2012\end{array}$ \\
\hline $\begin{array}{l}\text { S. tranquebarica and } \\
\text { S. olivacea }\end{array}$ & $\begin{array}{l}\text { Spherical shape } \\
0.40 \mathrm{~mm}\end{array}$ & $\begin{array}{l}\text { Spherical shape } \\
0.52 \mathrm{~mm}\end{array}$ & $\begin{array}{l}\text { Spherical shape } \\
0.60 \mathrm{~mm}\end{array}$ & $\begin{array}{l}\text { Elliptical shape. } 0.65 \mathrm{~mm} \text {. } \\
\text { Posteriorly spherical shape } \\
0.73 \mathrm{~mm}\end{array}$ & $\begin{array}{l}\text { Samuel and } \\
\text { Soundarapandian 2009, } \\
\text { Ates et al. } 2012\end{array}$ \\
\hline Ovalipes trimaculatus & $\begin{array}{c}\text { Spherical shape } \\
0.40 \mathrm{~mm}\end{array}$ & $\begin{array}{l}\text { Spherical shape } \\
0.52 \mathrm{~mm}\end{array}$ & $\begin{array}{c}\text { Spherical shape } \\
0.60 \mathrm{~mm}\end{array}$ & $\begin{array}{l}\text { Spherical shape } 0.65 \mathrm{~mm} \text {. } \\
\text { Posteriorly } 0.73 \mathrm{~mm}\end{array}$ & $\begin{array}{l}\text { Du Preez and Mcachlan } \\
1984\end{array}$ \\
\hline Ovalipes trimaculatus & $\begin{array}{l}\text { Spherical shape } \\
0.309-0.347 \mathrm{~mm}\end{array}$ & $\begin{array}{l}\text { Spherical shape } \\
0.326 \mathrm{~mm}\end{array}$ & $\begin{array}{c}\text { Spherical shape } \\
0.367 \mathrm{~mm}\end{array}$ & $\begin{array}{l}\text { Spherical shape } \\
0.372-0.378 \mathrm{~mm}\end{array}$ & This study \\
\hline
\end{tabular}


cesses of $O$. trimaculatus are similar to those reported for other portunids. However, since only external morphological features were used to characterize stages of embryonic development of species from the group, further examination based on histology and other techniques could reveal differences in the chronology of development between species. Also, as observed in other portunid crabs (Ates et al. 2012, Ikhwanuddin et al. 2012, Soundarapandian et al. 2013), in O. trimaculatus the embryonic development is synchronous in all eggs independently of their location in the egg mass. This pattern could reflect a homogeneous oxygen distribution to the developing embryos resulting from the ventilation of egg masses through abdominal flapping by brooding females, as reported for the species by Fernández et al. (2002).

The time required by $O$. trimaculatus to complete its embryonic development at $13^{\circ} \mathrm{C}$ was similar to the length of embryogenesis reported for other portunids, such as Liocarcinus depurator (33.4 days), L. holsatus (32.9 days) and L. pusillus (39.4 days) at a similar thermal regime $\left(12.5^{\circ} \mathrm{C}\right)$ (Wear 1974). In most crustaceans, length of embryonic development is strongly dependent on environmental conditions (Sun and Yu 1989), and especially on temperature (Heasman and Fielder 1983, Valdes et al. 1991, García-Guerrero et al. 2003). In Scylla serrata, for example, length of embryonic development exponentially decreases with increasing temperature (Hamasaki 2003), while in Necora puber it varies from 17.6 days at $25^{\circ} \mathrm{C}$ to 76 days at $10^{\circ} \mathrm{C}$ (Valdes et al. 1991). As pointed out by Campbell and Fielder (1987), in $P$. sanguinolentus and $C$. sapidus salinity also affects the duration of embryonic development, with accelerated embryonic development being observed at salinities below normal values of oceanic water. Taking this into consideration, the temperature and salinity conditions selected in this study $\left(13^{\circ} \mathrm{C}\right.$ and 33.8 days) resemble average conditions experienced by the species in the study area during the reproductive season. The results not only contribute to the understanding of the species' life cycle, but can also be considered in the design of control measures for fisheries management (e.g. implementation of fisheries bans during the reproductive season; egg-per-recruit modelling). Nevertheless, embryonic development of the species at $13^{\circ} \mathrm{C}$ was markedly longer than that reported for most portunids produced by aquaculture, typically incubated at higher temperatures common through their tropical geographic distributions, such as Portunus sanguinolentus (8-11 days at $28-31^{\circ} \mathrm{C}$ ) (Samuel and Soundarapandian 2009), P. pelagicus (6-7 days at 28$31^{\circ} \mathrm{C}$ ) (Soundarapandian and Tamizhazhagan 2009), Scylla serrata (7-9 days at $\left.27-30^{\circ} \mathrm{C}\right)$ (Churchill 2003), $S$. tranquebarica $\left(8.7 \pm 0.6\right.$ days at $\left.28.2 \pm 0.2^{\circ} \mathrm{C}\right), \mathrm{S}$. olivacea $\left(8.6 \pm 0.2\right.$ days at $\left.28.2 \pm 0.1^{\circ} \mathrm{C}\right)$ (Ates et al. 2012) and Arenaeus cribarius $\left(13.5 \pm 2.1\right.$ days at $\left.25.0 \pm 2.0^{\circ} \mathrm{C}\right)$ (Pinheiro and Franzoso 2002). Further research on $O$. trimaculatus should test other combinations of incubation temperatures, salinities and other environmental variables to achieve shorter embryonic development times suitable for competitive hatchery production while maintaining high embryonic survival.
Along with fecundity measurements, estimates of embryonic mortality can be used to infer the number of brooding females necessary to obtain a given amount of larvae or to anticipate live feed requirements for a batch of larvae production in hatcheries. Numerous sources of embryonic mortality are documented for brachyuran crabs, acting either at oviposition, during embryogenesis or at hatching (Kuris 1990). Among others, eggs can fail to attach to female pleopods (Choy 1988), detach due to mechanical stress (Kuhn et al. 2011) or die during incubation due to adverse external conditions such as nitrite concentration development in culture systems, poor oxygen availability, unsuitable salinities and temperatures, embryo predation, viral, bacterial and fungal diseases, epibionts and parasites (Balasundaram and Pandian 1982, Harper and Talbot 1984, Hamasaki et al. 2003). Also, mortality may be the result of unsuccessful fertilization of some eggs of a clutch (Choy 1988). Only accounting for mechanical stress, $O$. trimaculatus can lose up to $56.7 \%$ of its developing embryos (Brante et. al. 2004). Therefore, since "instantaneous mortality" estimations reported here do not account for mechanical egg loss, they should not be taken as absolute figures, but only used to compare embryonic mortality due to physiological stress between stages of development. Although a slight increase in instantaneous embryonic mortality was noted starting from stage III, the most noticeable mortality was observed during the hatching process (Table 2). This suggest that embryos should be treated gently during the final stages of development, especially at hatching, as indicated for other portunid crabs, Charybdis feriata (Sundarapandian et al. 2013) and Scylla serrata (Davis 2004a).

Eggs of portunid species show variations in size (Wear 1974). Positive relationships between female body size and egg size have been reported for several species within the group, including Ovalipes catharus (Haddon 1994) and Portunus pelagicus (Ravi and Manisseri 2013). In contrast, in this study no significant relationship was found between these variables, as has also been observed in S. serrata (Churchill 2003), Charybdis feriata (Soundarapandian et al. 2013) and some species of Cancer (Hines 1991).

As the embryos of $O$. trimaculatus develop, egg size increases gradually, reaching maximum dimensions by the time of hatching. Increases in egg volume and area recorded in this study are similar to those reported for other portunids (Fig. 2, Table 3), but are moderate in comparison to some species, whose eggs can double their volume at the end of embryonic development (Soundarapandian et al. 2013, Ates et al. 2012). In general, eggs of benthic marine decapods increase their initial water content by $33-40 \%$ during embryonic development (Stella et al. 1996). During the first stages of embryogenesis, yolk catabolism increases the amount of free metabolites providing the energy required for the formation of tissues, so more water, and consequently more volume, is required for solvation (Stella et al. 1996). Also, progressive intake and retention of water are necessary during metabolic reactions of lipid oxidation (Pandian 1967, 
Lardies and Wehrtmann 1997). At the final stages of development, egg volume increments are more closely related to the rise of internal osmotic pressure, which generates more water intake, and to the simultaneous or independent mechanisms that allow movements of the embryos aimed at tearing the chorion and initiating hatching (Davis 1965, Lardies and Wehrtmann 1997, Pandian 1967). In O. trimaculatus in particular, marked increments in egg dimensions were observed between stages I and II, when the thoracic-abdominal plate and the primordium of the embryo start forming appendages and grow, requiring extra space within the egg. Also, a pronounced increase in egg dimensions was observed in the transition from stages III to IV, when embryogenesis completes and formed embryos enlarge their appendages. Moreover, these differences are statistically significant (Fig. 2). In regard to shape variations, eggs of $O$. trimaculatus remain spherical throughout embryonic development, showing nearto-zero elongation index values in all stages of development, just like the eggs of most brachyuran crabs (Hines 1982, Yamaguchi 2001, Pinheiro and Hattori 2003), including those from the closely related Ovalipes catharus (Haddon 1994, Ravi and Manisseri 2013).

It is known that in marine organisms, including crustaceans, pigment content determines egg quality to a great extent due to its critical role in many metabolic processes, including egg respiration and vitamin A production, its protective action against the effects of oxygen, UV and ionizing radiation, and its function in gene expression, among others (Craik 1985, Kalinina et al. 2009, Wade et al. 2015). Egg colour progression throughout embryogenesis is common in crustaceans, and in general terms it reflects the initial consumption of typically yellow or orange-coloured yolk, superimposed on the production of red-, brown- and greycoloured pigments on chromatophores and eyes during advanced stages (Sigana 2002, Parimalam 2001). Although this pattern of colour change throughout development has been reported in studies conducted on other portunid species (Ravi and Manisseri 2013), to our knowledge there are no objective colour classifications (with the Pantone ${ }^{\circledR}$ Colour Formula Guide), as reported in this study.

This work provides the first information on the embryogenesis of $O$. trimaculatus. Although experimental results were obtained from incubations at a single combination of temperature and salinity, they represent a necessary step preceding studies aimed at understanding the effects of environmental variables on embryogenesis. Further experimental work is necessary to optimize hatchery practices and to supplement the pre-existing knowledge on the life cycle of the species in the wild, for management purposes.

\section{ACKNOWLEDGEMENTS}

We thank the personnel of the nautical and aquarium services (CCT CONICET-CENPAT) for their collaboration in crab collection and setting of experimental work. This work was carried out in the framework of the projects PIP 0354/14 and PICT-2014-1498 granted by the National Council of Science and Technology (CONICET).

This study includes partial contents of the doctoral thesis of A. Martelli at the Universidad Nacional of Comahue (Argentina) and was financed with a research grant from the National Council for Scientific and Technical Research (CONICET, Argentina).

\section{REFERENCES}

Adiyodi R. 1988. Reproduction and development. In: Burggren W., McMahon B.R. (eds) Biology of the land crabs. Academic Cambridge, England Press. 139-185. http://dx.doi.org/10.1017/cbo9780511753428.006

Allan G., Fielder D. 2004. Mud crab aquaculture in Australia and Southeast Asia. Proceedings of a Scoping Study and Workshop. ACIAR. 54.

Alvarez J., Velíz C., Meruane J. 2009. Molt cycle stages of the paddle crab Ovalipes trimaculatus (de Hann, 1833) based on observations of the external morphology. Rev. Biol. Mar. Oceanogr. 44: $217-225$

http://dx.doi.org/10.4067/S0718-19572009000100022

Arnaud P.M., Beurois J., Noel P. 1972. Portunidae et Grapsidae des îles Saint Paul et Amsterdam, Océan Indien (Decapoda, Brachyura). Beaufortia 20: 7-14.

Ates M.C.D., Quinitio G.F., Quinitio T., et al. 2012. Comparative study on the embryonic development of three mud crabs Scylla spp. Aquac. Res. 43: 215-225. http://dx.doi.org/10.1111/j.1365-2109.2011.02818.x

Balasundaram C., Pandian T.J. 1982. Egg loss during incubation in Macrobrachium nobilii (Henderson and Mathai). J. Exp. Mar. Biol. Ecol. 59: 289-299. http://dx.doi.org/10.1016/0022-0981(82)90122-8

Bas C.C., Spivak E.D., Anger K. 2008. Variation in early developmental stages in two populations of an intertidal crab, Neohelice (Chasmagnathus) granulata. Helgol. Mar. Res. 62: 393-401. http://dx.doi.org/10.1007/s10152-008-0128-5

Boschi E. 1997. Las pesquerías de crustáceos decápodos en el litoral de la República Argentina. Invest. Mar. Valparaíso. 25: 19-40.

Brante A., Fernandez M., Eckerle L., et al. 2003. Reproductive investment in the crab, Cancer setosus, along a latitudinal cline: egg production, egg losses and egg ventilation. Mar Ecol Prog Ser. 251: 221-232. http://dx.doi.org/10.3354/meps251221

Brante A., Cifuentes H.O.P., Wolf A., et al. 2004. Latitudinal comparisons of reproductive traits in five brachyuran species along the Chilean coast. Rev. Chil. Hist. Nat. 77: 15-27. http://dx.doi.org/10.4067/S0716-078X2004000100003

Campbell G.R., Fielder D.R. 1987. Occurrence of a prezoea in two species of commercially exploited portunid crabs (Decapoda, Brachyura). Crustaceana 52: 202-206. http://dx.doi.org/10.1163/156854087X00240

Catacutan M.R., Eusebio P.S., Teshima S. 2003. Apparent digestibility of selected feedstuffs by mud crab, Scylla serrate. Aquaculture 216: 253-261. http://dx.doi.org/10.1016/S0044-8486(02)00408-8

Choy S.C. 1988. Reproductive Biology of Liocarcinus puber and L. holsatus (Decapoda, Brachyura, Portunidae) from the Gower Peninsula, South Wales. Mar. Ecol. 9: 227-241. http://dx.doi.org/10.1111/j.1439-0485.1988.tb00330.x

Churchill G.R. 2003. An investigation into the captive spawning, egg characteristic and egg quality of the mud crab (Scylla serrata) in South Africa. Workshop of mud crab culture, ecology and fisheries, Can Tho University, Vietnam, 8-10 th January 2001.

Craik J.C.A. 1985. Egg quality and egg pigment content in salmonid fishes. Aquaculture 47: 61-88. http://dx.doi.org/10.1016/0044-8486(85)90008-0

Cronin T.W., Jinks R.N. 2001. Ontogeny of vision in marine crustaceans. Amer. Zool. 41: 1098-1107. http://dx.doi.org/10.1668/0003-1569(2001)041[1098:OOVIM C]2.0.CO;2

Davis C. 1965. A study of the hatching process in aquatic invertebrates: XX. The blue crabs Callinectes sapidus Rathbun. Chesapeake Sci. 6: 201-208 http://dx.doi.org/10.2307/1350814

Davis J.A., Churchill G.J., Hecht T., et al. 2004a. Spawning characteristics of the South African mud crab Scylla serrata (Forskål) 
in captivity. J. World Aquacult. Soc. 35: 121-131. http://dx.doi.org/10.1111/j.1749-7345.2004.tb01068.x

Davis J.L.D., Young-Williams A.C., Aguilar R., et al. 2004b. Differences between hatchery-raised and wild blue crabs: Implications for stock enhancement potential. T. Am. Fish. Soc. 133: $1-114$ http://dx.doi.org/10.1577/T03-004

Dellatorre F.G., Pisoni J.P., Barón P.J., et al. 2012. Tide and wind forced nearshore dynamics in Nuevo Gulf (Northern Patagonia, Argentina): Potential implications for cross-shore transport. J. Mar. Syst. 96-97: 82-89. http://dx.doi.org/10.1016/j.jmarsys.2012.02.004

Dellatorre F.G., Lovrich G., Rojas L., et al. 2014. Seasonal abundance and vertical distribution of crab larvae from northern Patagonia (Argentina): implications for their transport in a biogeographic boundary region. Mar. Biol. Res. 10: 37-50. http://dx.doi.org/10.1080/17451000.2013.793805

Dima J.B., De Vido N.A., Leal G.A., et al. 2009. Biochemical composition of the Patagonian stone crab Platyxanthus patagonicus A. Milne Edwards, 1879 (Platyxanthidae: Brachyura) and its fluctuation through the reproductive cycle. Sci. Mar. 73: 423-430.

http://dx.doi.org/10.3989/scimar.2009.73n3423

Dima J.B., Barón P.J., Zaritzky N.E. 2012. Mathematical modeling of the heat transfer process and protein denaturation during the thermal treatment of Patagonian marine crabs. J. Food Eng. 113: $623-634$ http://dx.doi.org/10.1016/j.jfoodeng.2012.07.007

Dima J.B., Barón P.J., Zaritzky N.E. 2014. Pasteurization conditions and evaluation of quality parameters of frozen packaged crab meat. J. Aquat. Food Prod. T. 92: 54-66.

Dohle W., Gerberding M., Hejnol A., et al. 2004. Cell lineage, segment differentiation, and gene expression in crustaceans. In: Scholtz G. (ed) Evolutionary developmental biology of Crustacea. Crustacea Issues 15: 95-133

Du Preez, H.H., McLachlan, A. 1984. Biology of the three spot swimming crab, Ovalipes punctatus (De Haan) III. Reproduction, fecundity and egg development. Crustaceana 47(3): 285-297. http://dx.doi.org/10.1163/156854084X00540

FAO. 2015. FishStatJ, a tool for fishery statistics analysis. Release: 2.1.0.

Felder D.L., Martin J.W., Goy J.W. 1985. Patterns in early postlarval development of decapods. In: Wenner A.M. (ed.), Larval growth, 2. Crustacean issues. Balkema Press, Rotterdam, Netherlands. 163-226.

Fenucci J.L., Boschi.E.E. 1975. Contribución al conocimiento biológico del cangrejo comercial de las aguas costeras de la provincia de Buenos Aires, Ovalipes trimaculatus (de Haan) (Crustacea, Decapoda, Portunidae). Physis. 89: 291-308.

Fernández M., Brante A. 2003. Brood care in Brachyuran crabs: the effect of oxygen provision on reproductive costs. Rev. Chil. Hist. Nat. 76: 157-168. http://dx.doi.org/10.4067/S0716-078X2003000200003

Fernández M., Pardo L.M., Baeza J.A. 2002. Patterns of oxygen supply in embryo masses of brachyuran crabs throughout development: the effect of oxygen availability and chemical cues in determining female brooding behavior. Mar. Ecol. Prog. Ser. 245:181-190. http://dx doi.org/10.3354/meps245181

García-Guerrero M., Villarreal H., Racotta S. 2003. Effect of temperature on lipids, proteins, and carbohydrates levels during development for egg extrusion to juvenile stage of Cherax quadricarinatus (Decapoda: Parastacidae). Comp. Biochem. Phys. A. 135: 147-154. http://dx.doi.org/10.1016/S1095-6433(02)00354-9

Garcia-Guerrero M., Hendrickx M.E. 2004. Embryology of decapod crustaceans I: Complete embryonic development of the mangrove crabs Goniopsis pulchra and Aratus pisonni (Decapoda: Brachyura). J. Crustac. Biol. 24: 666-671. http://dx.doi.org/10.1651/C-2497

Haddon M. 1994. Size-fecundity relationships, mating behavior and larval release in the New Zealand paddle crab, Ovalipes catharus (White 1843) (Brachyura: Portunidae). New Zeal. J. Mar. Fresh. 28: 329-334. http://dx.doi.org/10.1080/00288330.1994.9516622

Hamasaki K. 2003. Effects of temperature on the egg incubation period, survival and developmental period of larvae of the mud crab Scylla serrata (Forskal) (Brachyura: Portunidae) reared in the laboratory. Aquaculture 219: 561-572.
http://dx.doi.org/10.1016/S0044-8486(02)00662-2

Hamasaki K., Fukunaga K., Maruyama K. 2003. Egg development and incubation period of the swimming crab Portunus trituberculatus (Decapoda: Portunidae) reared in the laboratory. Crustac. Res. 32: 45-54.

Harper R.E., Talbot P. 1984. Analysis of the epibiotic bacteria of lobster (Homarus) eggs and their influence on the loss of eggs from the pleopods. Aquaculture 36: 9-26. http://dx.doi.org/10.1016/0044-8486(84)90050-4

Heasman M.P., Fielder D.R. 1983. Laboratory spawning and mass rearing of the mangrove crab, Scylla serrata (Forskal), from first zoea to first crab stage. Aquaculture 34: 303-316. http://dx.doi.org/10.1016/0044-8486(83)90210-7

Hines A.H. 1982. Allometric constraints and variables of reproductive effort in brachyuran crabs. Mar. Biol. 69: 309-320. http://dx.doi.org/10.1007/BF00397496

Hines A.H. 1991. Fecundity and Reproductive output in nine species of Cancer crabs (Crustacea, Brachyura, Cancridae). Can. J. Fish. Aquat. Sci. 48: 267-275. http://dx.doi.org/10.1139/f91-037

Ikhwanuddin M., Ara M.N., Siti-Aimuni H., et al. 2012. Fecundity, embryonic and ovarian development of blue swimming crab, Portunus pelagicus (Linnaeus, 1758) in coastal Water of Johor, Malasya. Pak. J. Biol. Sci. 15: 720-728. http://dx.doi.org/10.3923/pjbs.2012.720.728

Josileen J. 2011. Captive spawning, hatching and larval development of crucifix crab, Charybdis feriatus (Linnaeus, 1758). J. Mar. Biol. Assoc. India. 53: 35-40.

Kalinina M.V., Zadorozhnyib P.A., Vinnikovac N.A. 2009. Sexual Cycle Properties and Changes in Carotenoid Levels in Ovary of Japanese Mitten Crab Eriocheir japonica from Rivers of Primorye. J. Dev. Biol. 39 (3): 176-182. http://dx.doi.org/10.1134/s1062360409030072

Kuhn P.S., Graham S., Choi J.S. 2011. Influence of senescent algae, temperature, tides, currents, and embryo detachment on Chionoecetes opilio (Snow crab) larval release. J. Crustac. Biol. 31: 100-105. http://dx.doi.org/10.1651/10-3326.1

Kuris A.M. 1990. A review of patterns and causes of crustacean brood mortality. In: Wenner A. and Kuris A. (eds), Crustacean egg production. Crustacean issues 7: 117-141, Balkema, Rotherdam.

Lardies M.A., Wehrtmann I.S. 1997. Egg production in Betaeus emarginatus (H. Milne Edwards, 1837) (Decapoda: Alpheidae): fecundity, reproductive output and chemical composition of eggs. Ophelia 46: 165-174. http://dx.doi.org/10.1080/00785326.1997.10432582

Lee R.F., O’Malley K., Oshima Y. 1996. Effects of toxicants on developing oocytes and embryos of the blue crab, Callinectes sapidus. Mar. Environ. Res. 42: 125-128. http://dx.doi.org/10.1016/0141-1136(95)00079-8

Lindner B. 2005. Impacts of mud crab hatchery technology in Vietnam. Assessment Series Report N ${ }^{\circ} 36$, October 2005. ACIAR projects FIS/1992/017 and FIS/1999/076. Economic Research Associates and School of Agricultural and Resource Economics University of Western Australia. 68 pp.

MacDonald J.M., Shields J.D., Zimmer-Faust R.K. 1988. Acute toxicities of eleven metals to early life-history stages of the yellow crab Cancer anthonyi. Mar. Biol. 98: 201-207. http://dx.doi.org/10.1007/BF00391195

Melo G.A.S. 1996. Manual de identificação dos Brachyura (caranguejos e siris) do Litoral Brasileiro. Ed. Plêiade/FAPESP, São Paulo, 604 pp.

Moriyasu M., Lanteigne C. 1998. Embryo development and reproductive cycle in the snow crab, Chionoecetes opilio (Crustacea: Majidae), in the southern Gulf of St. Lawrence, Canada. Can. J. Zool. 76: 2040-2048. http://dx.doi.org/10.1139/z98-147

Müller Y.M.R., Nazari E.M., Simoes-Costa M.S. 2003. Embryonic stages of the freshwater prawn Macrobrachium olfersi (Decapoda, Palaemonidae). J. Crustac. Biol. 23: 869-875. http://dx.doi.org/10.1651/C-2408

Nagao J., Munehara H., Shimazaki K. 1999. Embryonic development of the hair crab Erimacrus isenberckii. J. Crustac. Biol. 19: $77-83$. http://dx.doi.org/10.1163/193724099X00277

Pandian T.J. 1967. Changes in chemical composition and caloric content of developing eggs of the shrimp Crangon crangon. Helgol. Wiss. Meeresunters. 16: 216-224. http://dx.doi.org/10.1007/BF01611705 
Parimalam K. 2001. Embryonic and larval development of the hermit crab, Clibanarius longitarsus (de Haan) (Crustacea: Decapoda: Anomura). MSc. thesis: Annamalai Univ. India.

Pinheiro M.A.A., Franzoso A. 2002. Reproduction of the speckled swimming crab Arenaus cribrarius (Brachyura: Portunidae) on the Brazilian coast near $23^{\circ} 30^{\prime}$ S. J. Crustac. Biol. 22: 416-428. http://dx.doi.org/10.1651/0278-0372(2002)022[0416:ROTSSC 12.0.CO;2

Pinheiro M.A.A., Hattori G.Y. 2003. Embryology of the mangrove crab Ucides cordatus (Brachyura: Ocypodidae). J. Crustac. Biol. 23: 729-737. http://dx.doi.org/10.1651/C-2334

Quinitio E. 2009. Advances in mud crab hatchery and nursery. Infofish International, 3: 16-18.

Ravi R., Manisseri. M.K. 2013. Alterations in size, weight and morphology of the eggs of blue swimmer crab, Portunus pelagicus Linnaeus, 1758 (Decapoda, Brachyura, Portunidae) during Incubation. Turk. J. Fish. Aquat. Sci. 13: 509-515 http://dx.doi.org/10.4194/1303-2712-v13 314

Rivas A., Ripa P. 1989. Variación estacional de la estructura termohalina de golfo Nuevo, Argentina. Rev. Geofis. (Mex) 28: 3-23.

Samuel N.J., Soundarapandian P. 2009. Embryonic development of commercially important portunid crab Portuns sanguinolentus (Herbst). J. Anim. Vet. Adv. 1: 32-38.

Scholtz G., Dohle W. 1996. Cell lineage and cell fate in crustacean embryos - a comparative approach. Int. J. Dev. Biol. 40: 211-220.

Scholtz G., Wolff C. 2013. Arthropod embryology: cleavage and germ band development. In: Minelli A, Boxshall G., Fusco G. (eds), Arthropod Biology and Evolution: Molecules, Development and Evolution. Springer. pp. 63-89. http://dx.doi.org/10.1007/978-3-642-36160-9 4

Sigana D.A. 2002. Breeding cycle of Thalamita crenata (Latreille, 1829) at Gazi Creek (Maftaha Bay), Kenya. Western Indian Ocean. J. Mar. Sci. 1: 145-153.

Soundarapandian P., Tamizhazhagan T. 2009. Embryonic development of commercially important swimming crab Portunus pelagicus (Linnaeus). Curr. Res. J. Biol. Sci 1: 106-108.

Soundarapandian P., Ilavarasan N., Varadharajan D., et al. 2013. Embryonic development of commercially important Portunid crab Charybdis feriata (Linnaeus). J. Mar. Sci. Res. Dev. 3: 122. http://dx.doi.org/10.4172/2155-9910.100012

Stella V., Lopez L., Rodriguez E. 1996. Fecundity and brood bio- mass investment in the estuarine crab Chasmagnathus granulata Dana 1851. Crustaceana 69: 307-312. http://dx.doi.org/10.1163/156854096X00907

Stevens B.G. 2006. Embryo development and morphometry in the blue king crab Paralithodes platypus studied by using image and cluster analysis. J. Shellfish Res. 25: 569-576. http://dx.doi.org/10.2983/0730-8000(2006)25[569:EDAMIT]2 $0 . \mathrm{CO} ; 2$

Stevens B.G., Swiney K.M., Buck L. 2008. Thermal effects on embryonic development and hatching for blue king crab Paralithodes platypus (Brandt, 1850) held in the laboratory, and a method for predicting dates of hatching. J. Shellfish Res. 27: 1255-1263.

Sun Y., Yu Y. 1989. A preliminary study of artificial rearing of juvenile Charybdis (Charybdis) japonica. Mar. Csi. Haiyang. Hexue. 3: 43-47.

Valdes L., Alvarez-Ossorio M.T., Gonzalez-Gurriaran E. 1991. Influence of temperature on embryonic and larval development in Necora puber (Brachyura, Portunidae). J. Mar. Biol. Assoc. U.K. 71: 787-789. http://dx.doi.org/10.1017/S0025315400053455

Vallina M., Sal Moyano M.P., Cuartas E.I., et al. 2014. Reproductive system and size maturity of the paddle crab Ovalipes trimaculatus (Brachyura: Portunidae) along the Argentine coast. J. Crustac. Biol. 34: 357-366 http://dx.doi.org/10.1163/1937240X-00002239

Wade N.M., Gabaudan J., Glencross B.D. 2015. A review of carotenoid utilization and function in crustacean aquaculture. Rev. Aquaculture. http://dx.doi.org/110.1111/raq.12109

Wear R.G. 1974. Incubation in British decapod crustacean and the effects of temperature on the rate and success of embryonic development. J. Mar. Biol. Assoc. U.K. 54: 745-762. http://dx.doi.org/10.1017/S0025315400022918

Yamaguchi T. 2001. Incubation of eggs and embryonic development of the fiddler crab Uca lactea (Decapoda, Brachyura, Ocypodidae). Crustaceana 74: 449-458. http://dx.doi.org/10.1163/156854001750243036

Zmora O.A., Findiesen J., Stubblefield V.F., et al. 2005. Large-scale juvenile production of the blue crab Callinectes sapidus. Aquaculture 244: 129-139. http://dx.doi.org/10.1016/j.aquaculture.2004.11.012 